\title{
Discovering subjectivity: A subjective world of meanings in the stories of the twilight of life
}

\begin{abstract}
Pointing to the subjective nature of human life, theorists argue that only in a dialogue with another person does the human disclose meanings important to him or her. The interpretation and analysis of stories with regard to the included subjective meanings included in them as manifestations of human subjectivity seem to be the most effective when undertaken in the hermeneutic approach where psychology and philosophy meet. In the paper advantages of a selfnarrative method based on the principles of hermeneutic psychology have been presented. This method has been applied to analyse the stories told by ten persons of senior age and obtained through a narrative interview. This analysis has served to verify the mentioned method, to recognise the respondents'subjective world of meanings as well as to deepen the reflection on the subjective nature of human life. The exemplary analysis of two out of ten self-narratives obtained in the research have been presented in the article. Similarly to the theoretical reflection included in the text, the research results join the ongoing discussion in contemporary psychology over the legitimacy of the use of qualitative methods.
\end{abstract}

Key words: self-narrative, subjective meanings, autobiographical experience, hermeneutic interpretation, late adulthood

\section{The role of qualitative methods in the study of a subjective world of meanings}

Qualitative methods applied in psychological studies and determined by the experimental paradigm enable to collect and analyse a large amount of data and to draw general conclusions. The qualitative paradigm is characterised by the lack of objective verifiability and nonstandardness of test procedures, by which it is to a lesser extent involved in the formulation of universally applicable principles explaining human behaviour. The research, description and interpretation of facts of an individual's psyche are its primary functions. Qualitative methods do not concentrate on the verification of hypotheses but on free communication and unhindered utterance of respondents, making it possible to reveal their personal meanings and to obtain a holistic picture of their psyche.

Arguing the legitimacy of the use of qualitative methods, Straś-Romanowska (2000) divides psychological phenomena into facts of nature and facts of culture. The former ones are independent of the subject's consciousness and arise from the biological structure of the body and for this reason they are subject to the laws of nature. As such, they should be studied in an objective manner in accordance with the paradigm of qualitative methods. Facts of culture comprise conscious responses, attributed meanings as well as free choices of individuals characterised by subjectivity and constituting their personal uniqueness. They relate to the phenomena involving the entire personality, making it impossible to reduce them to the quantitative data of the objectivist paradigm. The phenomenological or internal perspective is suitable for this type of phenomena.

Theories emphasising the subjectivity of a human indicate the role of qualitative methods in the research of a subjective world of meanings. The notion of subjectivity derives from philosophical anthropology, which assumes that persons (personal beings) are characterised by reflexive awareness and cognitive openness - they actively analyse encountered events, have doubts, consider dilemmas and seek meanings in external events as well as in their own lives. Cognitive openness allows them to cross the boundaries present in their reality and to search for new solutions and meanings.

Phenomenological-existential orientation present in psychology draws from the above-mentioned understanding of subjectivity; its representatives distinguish two aspects of

\footnotetext{
Cardinal Stefan Wyszyński University in Warsaw, Faculty of Christian Philosophy, Institute of Psychology

Corresponding author: w.zagorska@uksw.edu.pl
} 
this concept: 'subjective self' and 'objective self' (Bobryk, 1981; Pervin \& John, 1997). 'Objective self' fulfils important functions in the regulation of behaviour thanks to such phenomena as self-awareness, self-knowledge and self-structure. The problem of this area of subjectivity lies within the quantitative and empirical paradigm. 'Subjective self' is connected with a specifically human feature, i.e. the ability to self-govern and to think about oneself. This is defined as the centre of human activity (Straś-Romanowska, 2004). 'Personal self' is connected with 'existence' - the existence of a human in the world who remains in constant relationship with it and with other beings. In order to understand 'personal self' one must reach to the subjective world of human meanings, which concerns his/her existence at three levels: 'self - the world of nature', 'self - the world of interpersonal relations' and 'self - the world of responses to oneself'. According to Uchnast (1983), capturing 'the personal self' is only possible in a situation equivalent to the existential subsistence of a human in the world, i.e. through 'I - you'.

In the light of the above-mentioned expressions, human identity consists of subjectively experienced meanings, inscribed in a system of meanings present in the world in which such a human lives. Such structure of identity may only be created thanks to a specifically human ability, i.e. the ability to use a language. The knowledge about oneself and about the world takes the shape of a narrative in which meanings are inscribed. Many concepts of the so-called narrative identity are based on the above assumption; they presume that through narration and dialogue a person may identify and recognise oneself as well as that the form of a self-narrative reflects the shape of human identity (McAdams, 1993; Ricoeur, 1992; Riessman, 2008; Gergen \& Gergen, 2011).

The use of qualitative methods, which rely on free narration and dialogue, is justified when the inner world of meanings of a human perceived in a subjective way is the subject matter of research. In opposition to the quantitative and explanatory model, this research model is defined as the understanding one. The method and general theory of understanding and interpretation of a text is one of the faces of hermeneutics.

\section{Hermeneutics as a method of understanding the inner system of meanings}

At the core of hermeneutics there lies an assumption about human subjectivity and free human thought which manifests itself both in the facts of an individual's life as well as in the works of culture (Ricoeur \& Thompson, 1981). Reaching the hidden meanings underlying a text under interpretation is the goal of hermeneutics. In terms of hermeneutics, meaning is reflected in a dialogue - it is always addressed by a subject (text author) to a recipient and has two, subjective and objective, aspects. The subjective aspect of a meaning includes inner incommunicable experience of a subject, whose expression, available to a recipient, is called an objective meaning. A subject's true experience is non-transferable, because between his/her awareness and the awareness of a recipient of an utterance there is an insurmountable barrier; however, the meaning of such an experience that a subject wishes to convey lies between its subjective and objective meaning. The task of a recipient is to discover the meanings of a subject, i.e. to reach the meaning of his/her personal experiences by means of interpretive exploration of the conveyed objective meaning (Ricoeur, 1989). Reaching the internal logic of an utterance, which indicates deeper hidden meanings communicated by a subject and is the key according to which his/her own life is explained, is another goal of hermeneutics.

Attempting to understand the course of human life, one may not avoid the question on what exactly the subject-matter of understanding is and to what the meanings included in a text refer. According to Dilthey (1993), by own self-expression a subject communicates his/her inner spiritual life. This thesis, however, fails to account for the fact that mental life remains in indissoluble connection with the events of the external world surrounding such subject. This fact is taken into account by Austrian phenomenologist Landgrebe (1968) in his theory. In his approach, 'the position' contained in subject's experience - an internal reference to the surrounding world - is the subject-matter of the comprehension of a subject. It is defined by three elements: (1) all events, people and things present in the life of a subject, (2) events that he/she encounters, and (3) his/her free choices and decisions. A subject's story includes an attempt to understand his/her own position and to discover which of the above elements has the greatest impact on its shape. Following his/her interlocutor, a recipient of an utterance is trying to discover the variability of interlocutor's position and the meaning which he/she attaches to all of its elements.

The main method of hermeneutic understanding, so-called 'hermeneutic circle' is based on the understanding of an utterance as a whole by reference to the individual parts and understanding of each individual part by reference to the whole (Dilthey, 1982). The interpretation begins with an initial intuitive attempt to understand the text as a whole, to which the interpretation of its separate parts is subsequently referred. Better understanding of individual parts, in turn, enables deeper understanding of the whole text. This method allows gradual deepening of the understanding of meanings included in an utterance, which continues until one finds 'a good form' of interpretation that is free from internal contradictions. The lack of initial assumptions added to the interpretation as well as the interpreter's attitude of readiness and openness are the key conditions necessary to achieve comprehension (Radnitzky, 1970).

Hermeneutics adopts research assumptions such as individualism, contextualism and historicism. Individualism means the examination of the manifestations of a human's subjective existence without referring them to certain universality, treating the world of meanings as a distinguished separate entirety. Contextualism assumes that, in order to reach subjective meanings 
of an individual, it is necessary to take into account the context in which such person lives, that is both his/her immediate surrounding as well as culture of which he/she is a participant. On the other hand, according to the principle of historicism, in order to understand the behaviour of individuals and reach the world of their subjective meanings, one should take into account their history, consisting of both events beyond their control as well as their own choices with all the consequences. In the light of the above, the analysis of a self-narrative constitutes one of the most significant ways to explore the subject's inner world of meanings.

\section{Reaching the world of subjective meanings through the interpretation of a self-narrative}

In the light of the narrative theory of identity, human beings live their lives as a story. A narrative concerning their own lives is more than an objective report on facts present in their biographies. A subject actively constructs it by attaching meanings to specific events, by omitting others and even by incorporating fiction and misconceptions into it. A self-narrative regarding one's own life allows to form identity and to set oneself goals anchored in the future. The subjectivity of humans, who reflect upon their own lives and attach meaning to them, is realised in a self-narrative. 'Subjective self' plays a role of a narrative author here while 'objective self' the role of its character. In this way by means of a self-narrative humans live their lives at the same time evaluating, commenting and interpreting them (Sarbin, 1986). This process is inextricably linked to the attachment of meanings to the events of a person's own life.

The distinction of the basic element constructing the interpretation of a narrative, i.e. autobiographical experience, is very useful in such interpretation. The external aspect of this experience relates to the world, in which a person is immersed at the time, as well as its impacts. The internal aspect of the autobiographical experience is connected with thoughts and emotions.

Experience is stored in autobiographical memory. Encoding it according to its meaning to an individual is the function of memory. Experiences important to the 'self' are remembered better and faster recalled from memory, therefore the mere availability of the memory of some experience indicates its importance and significance (Maruszewski, 2011). Reconstruction of the system of subjective meanings included in a self-narrative requires recognition of experiences and thoughts, vital to an individual (internal aspect).

Hermeneutic interpretation proceeds on the attempt to fully and generally understand a text. This stage is called pre-comprehension. By virtue of the leading role of intuition in it, pre-comprehension may consist in the assignment to the analysed text of metaphors reflecting its holistic and contextual character, e.g. metaphors of literature - drama, romance, chronicle etc. (Frye, 1963) or metaphors depicting motifs (dominant in a narrative) travel, suffering, competition, fight, etc. (Elsbree, 1982). Pre-comprehension may also include an attempt to address the question concerning a narrative, role and perspective of a narrator and a participant in the described events.

The subsequent stage of interpretation is to locate partial meanings included in a narrative. In the case of the studies presented below, a formal analysis of a text and analysis of the links between experiences included in the story and the feelings of an individual were used at this stage.

A formal analysis is based on the assumption that the linguistic structure of a narrative constitutes the reflection of its semantic structure. A topic which relates to particular dimensions of a respondent's life is a distinguished element at this level of analysis. In order to determine the structure of a narrative, it is required to define the frequency of given topics, the amount of time devoted to them in the story as well as connections between these topics. This allows to give an utterance some transparency and to select the first draft of subjective meanings. Memory availability and recurrence of a topic in a narrative shows whether a respondent attributes importance to a given topic (Źurko, 2004).

The following stage of the interpretation focuses on specific autobiographical experiences mentioned by a narrator. The analysis of terms used in the description of such experience serves to discover the feelings which are combined with a given experience. Such feelings and emotions as well as comments added to the experience by a respondent indicate its subjective importance and meaning.

Meanings combined with particular experiences confirm or weaken the results obtained in the course of formal analysis. On the basis of the synthesis of these two stages, one may already conclude about an individual's general system of meanings. The result of this stage is compared with the obtained result of intuitive understanding of the whole done in the pre-comprehension stage. Any inconsistencies are an indication for a deeper analysis of individual experiences and topics. An interpretation may be ended when its form is internally coherent and consistent and results in the restoration of the structure of meanings communicated by a subject during the narration.

The hermeneutic analysis of a self-narrative enables to understand the world of individual meanings of a subject taking full account of his/her subjectivity and individuality. This method is, however, exposed to various difficulties both at the stage of formation as well as the interpretation of a narrative. Empirical verification of this method is essential in order to determine the conditions under which it provides reliable results.

\section{Research issues and hypothesis}

In order for a subject to reveal meanings essential to him/herself in the course of narration, he/she must develop adequate motivation for such action. Both the shape of the relationship with a recipient as well as the topic of a narrative determine such motivation. The role of a subject is to organise the thread of narration, thanks to which it 
is not merely a chronological sequence of events, but it reveals meanings that are vital to him/her (Hermans \& Hermans-Jansen, 1995). In the presented research a method of conducting an interview has been developed with regard to its effectiveness in the scope of motivating a subject to disclose personal meanings.

The hermeneutic analysis of a self-narrative does not use reliable and objectively verifiable statistical methods, hence it is exposed to the mistake of subjectivism. Capturing the semantic structures of a subject requires the rejection of an interpreter's own perspective and a glance at the experiences of an individual from his/her point of view (Denzin \& Lincoln, 2005). In the course of the research the attempt to meet this assumption was undertaken as well as the adopted method for the interpretation of a narrative was verified. The comparison of the results with the opinion of respondents was a criterion of credibility of this method. According to Ricoeur's theory (1989), in a selfnarrative subjects convey the meaning of their own inner incommunicable experience. Therefore, they are experts regarding their own system of meanings and may confirm or reject the results of interpretation.

The aim of this research has been to analyse the subjective meanings of an individual communicated in a self-narrative without generalising the results and relating them to the generally applicable principles of psychology. It was assumed that the selected type of interpretation would enable to reach the authentic world of a subject's meanings. The hypothesis verified in this paper concerned the accuracy of the used method of interpretation.

\section{The method}

\subsection{The research scheme}

The research has been based on assumptions concerning the subjectivity of an individual and the narrative nature of his/her identity as well as on the principles of hermeneutic understanding. In view of the adopted theoretical system, the lack of restrictions on the length of an utterance and the accurate transcription of its content have been emphasised. The research consisted of three stages, the first one being the interviews, the content of which was transcribed, followed by the interpretation of the collected material and the final stage in which the analysis results were referred to the opinion of respondents and these opinions were used to reflect on the correctness of the applied method.

\subsection{Applied techniques}

\subsubsection{Manner of conducting interviews}

A self-narrative was obtained by means of the first stage of an autobiographical interview according to Schütze (1976, as in Helling, 1990), modified for the purpose of the research. This technique is based on the assumption that, in order to prompt a respondent to reveal personal meanings, the question addressed to them should be open. The form of the question should assure respondents that it is their personal opinions that are of interest as well as that their utterance is in no way limited by researcher's expectations. Schütze assigns an important role to non-verbal guidance as evidence of listener's interest and understanding. A respondent provides free responses to a so-called narrative stimulus.

In addition, in the course of the preparation of the interview, elements of the research procedure (Żurko, 2004) were used, according to which a respondent must have time to consider and prepare the content of an utterance while the topic of the question should take a specific and, to some extent, narrow form so as to encourage a respondent to talk about significant events.

Eventually, the interview consisted of the following stages:

(1) The content of the narrative stimulus printed on a piece of paper was read to a respondent:

In life we face a lot of experiences, sometimes difficult, and sometimes very beautiful ones. Some of them remain in our memory for long and are very valuable to us. I would like to ask you to tell me about such important experiences for you, so that thanks to your story I could learn more about life and especially about what is really important.

After a respondent familiarised him/herself with the content of the stimulus, he/she was requested to ponder over it. Answers were provided only at the subsequent meeting, several days later. The printed content of the narrative stimulus was left at respondents' homes.

(2) At the next meeting, the researcher repeated the narrative stimulus. A respondent provided a free self-narrative. The utterance recipient refrained from interruptions, but showed interest and attentively listened to the entire utterance. The story ended when a respondent expressly indicated that the topic had been exhausted.

\subsubsection{Manner of interview interpretation}

The adopted method of interpretation was a synthesis of research procedure applied with the use of the assumptions of hermeneutic psychology and consisted of the following stages:

A) Pre-comprehension. A comprehensive, intuitive attempt to understand the text was the purpose of this stage. To achieve this, answers to the following questions were sought:

- What is the role and perspective of a narrator and a narrative protagonist?

What is the structure of a narrative?

B) Formal analysis. An attempt to determine the structure of a narrative in line with the principle that the formal structure constitutes the reflection of the semantic structure was the objective of this formal analysis. Frequency of separate topics as well as the amount of time dedicated to them in the story were analysed at this stage.

The specification of topics was based on the categories used in research by Bartosz (2004), to which 
extra categories arising from the interpreted narrative were added. The main assumption of the adopted division is the distinction into seven different contexts of human experience: personal, moral, existential, social, and emotional contexts as well as the one connected with education and associated with action. In each of these contexts specific topics were listed. Such distinction allowed to observe in what spheres of an individual's life a given experience occurred, which facilitated the identification of its meaning.

Experiences enumerated by a recipient were assigned, on the basis of the expressions and formulations used by $\mathrm{him} / \mathrm{her}$, to the topics prepared in the form of a table. The amount of time devoted to these experiences during an utterance was analysed. It was assumed that five lines of the transcription text constituting the description of a given experience were conventionally assumed to be one time unit. Some experiences related to more than one topic.

Frequency of separate topics and the amount of time devoted to their description were added.

The results of this stage of interpretation were summarised, pointing to the topics most frequently raised and discussed for the longest period of time. The discussion on the system of subject's meanings was undertaken on their basis.

C) Analysis of connections between autobiographical experiences and feelings as well as reflections of an individual. The purpose of this stage was to discover the connections between the enumerated experiences and feelings as well as reflections of an individual, which indicated and defined meanings attributed by him/her to given experiences.

In this part of the analysis the focus was mainly on the generalised experiences of an individual. A respondent's utterance confirming that a given experience had somehow been linked to an emotional event or utterances to which some reflection was referred were sought in the text. The most crucial sentences relating to a given experience were noted in the table, next to such experience.

Conclusions regarding the connections of feelings with a given experience were drawn on the basis of selected sentences. Such deduction regarding feelings was based on a list of feelings specified in the research performed by Bartosz (2004). Since the list assigns feelings to the abovementioned contexts of a personal life, the identification of a given feeling immediately pointed to the context in which a given experience impressed its meaning.

On the basis of the identified feelings and contexts as well as on the basis of reflection of a respondent, the conclusions were made with respect to meanings connected with particular experiences.

D) Synthesis of B and C stages. Meanings assigned to experiences were referred to the results relating to the meanings attributed to topics and obtained at the stage of formal analysis. On their basis changes were made in the outlined scheme of an individual's meanings as well as the content of these meanings was brought closer and deepened.
E) Synthesis of D and A stages. The obtained scheme of meanings was compared with the results from precomprehension. Conclusions about possible connections and dependencies between the results of these stages were made. Logical inadequacy of the results was a reference to a deeper analysis and the search for errors in the previous stages. Only when the results of stages A, B and C were internally consistent, the analysis was considered complete.

\subsubsection{Manner of result interpretation}

An individual's meanings obtained in the interpretation were formulated in the form of sentences uttered in the first person. Each meaning was assigned to a five- degree scale (1 - strongly disagree, 2 - disagree, 3 - neither agree nor disagree, 4 - agree, 5 - strongly agree). These sentences formed a questionnaire which was presented to respondents. The number of points marked by a respondent was subsequently added and divided by the highest score possible and finally multiplied by $100 \%$. The degree of consistency of the interpretation with a respondent's opinion, marked with CD, was thus obtained.

Behaviour and remarks made by respondents in the course of completing the questionnaires were taken into account during the verification of results and treated as additional indicators of their acceptance or rejection of the interpretation of their stories.

\section{Operational hypothesis}

It was expected that if the adopted method of interpretation avoided the error of subjectivism and leads to the identification of meanings communicated by an individual, then the degree of consistency of the interpretation with a respondent's opinion should amount to at least $70 \%$.

\subsection{Respondents and procedure}

People in late adulthood were invited to participate in the research, because of the fact that with age the environmental and biological factors play an increasingly smaller role in the functioning of the human psyche while the role of beyond-normative factors increases. This results in progressive individualisation of human life and stronger tendency to reflect and reinterpret the attitude to the world and events of one's own life. For this reason, the analysis of subjective meanings with people in their late adulthood seems particularly compelling.

Ten people of retirement age participated in the research. A sample analysis of the results of the two of them has been shown in this paper. They are: Mrs I. - a widow, 72 years of age, residing in a nursing home and Mrs J. - a widow, 71 years of age, living alone. Each of the research stages took place individually at the respondents' place of residence.

\section{Results}

\subsection{Interpretation of Mrs I.'s story}

\section{A) Pre-comprehension}

The narrator carries her story, explains the details of the occurring events and to a small extent refers to the protagonist's feelings. She talks about herself and her 
own experiences in a light manner at times and with great eagerness and emphasis at other times. This emphasis is particularly manifested when the narrator talks about the events which evoke resistance and objection in her. On several occasions the narrator directly addresses her listener.

The story protagonist often comes to the fore, but sometimes seems to vanish among the descriptions of various events and circumstances. There are very few descriptions of protagonist's relations with other characters in the story. The protagonist plays the main part and, from the very beginning, seems to be very independent.

The story both begins and ends with the description of her stay in the nursing home and is delivered in a chronological order. Descriptions of occurring events, independent of the protagonist, intertwine with the stories of his/her actions.

Table 1. Frequency of topics in Mrs I.'s story and the time devoted to them

\begin{tabular}{|c|c|c|c|c|}
\hline $\begin{array}{l}\text { Experience } \\
\text { context }\end{array}$ & Topic of experience & Events & Time & $\begin{array}{l}\mathbf{E} \\
\mathbf{T}\end{array}$ \\
\hline \multirow{20}{*}{ Personal } & Loss & 1. Her husband's illness and death & 5 & $\begin{array}{l}\mathrm{E}-1 \\
\mathrm{~T}-5\end{array}$ \\
\hline & \multirow{4}{*}{ Failure } & 1. Experience of war and occupation & 6 & \multirow{4}{*}{$\begin{array}{c}\mathrm{E}-4 \\
\mathrm{~T}-11\end{array}$} \\
\hline & & 2. Learning how to play the violin & 3 & \\
\hline & & 3. Illness - acute arthritis & 1 & \\
\hline & & 4. Education in secondary school & 1 & \\
\hline & \multirow{5}{*}{ Success } & 1. Acquiring coal from Germans & 2 & \multirow{5}{*}{$\begin{array}{l}\mathrm{E}-5 \\
\mathrm{~T}-8\end{array}$} \\
\hline & & 2. Graduating secondary technical school of economics & 1 & \\
\hline & & 3. Work at ZUS (Social Insurance Institution) & 1 & \\
\hline & & 4. Education at secondary technical school of fine arts & 2 & \\
\hline & & 5. Promotion to the head of professor's club & 1 & \\
\hline & \multirow{6}{*}{$\begin{array}{l}\text { Fight for herself and } \\
\text { her own convictions }\end{array}$} & 1. Defending her Father against Germans & 1 & \multirow{6}{*}{$\begin{array}{l}\text { E-6 } \\
\text { T-14 }\end{array}$} \\
\hline & & 2. Acquiring coal from Germans & 2 & \\
\hline & & 3. Opposition to the manager at FSO company & 3 & \\
\hline & & 4. Burying her husband according to his will & 2 & \\
\hline & & 5. Independence despite the illness & 1 & \\
\hline & & $\begin{array}{l}\text { 6. An official letter regarding the fact of being unfairly } \\
\text { treated by the director of the nursing home }\end{array}$ & 5 & \\
\hline & \multirow{4}{*}{$\begin{array}{l}\text { Personal } \\
\text { development }\end{array}$} & 1. Childhood spent in her family home & 5 & \multirow{4}{*}{$\begin{array}{l}\mathrm{E}-4 \\
\mathrm{~T}-10\end{array}$} \\
\hline & & 2. Learning to be clever during the war & 2 & \\
\hline & & 3. Education at secondary technical school of fine arts & 2 & \\
\hline & & 4. Enrolment on university studies & 1 & \\
\hline \multirow{6}{*}{ Moral } & \multirow{6}{*}{$\begin{array}{l}\text { Experience of human } \\
\text { injustice/ dishonesty }\end{array}$} & 1. Experience of war and occupation & 2 & \multirow{6}{*}{$\begin{array}{l}\text { E-6 } \\
\text { T-28 }\end{array}$} \\
\hline & & 2. Being forced to work by Germans & 2 & \\
\hline & & 3. Unfair treatment of her father by a German & 3 & \\
\hline & & 4. Meeting Rev. Maj & 3 & \\
\hline & & $\begin{array}{l}\text { 5. Demands made by her husband's daughter from } \\
\text { the previous marriage }\end{array}$ & 3 & \\
\hline & & 6. Operation of the nursing home & 15 & \\
\hline
\end{tabular}


Discovering subjectivity: A subjective world of meanings in the stories of the twilight of life

\begin{tabular}{|c|c|c|c|c|}
\hline $\begin{array}{l}\text { Experience } \\
\text { context }\end{array}$ & Topic of experience & Events & Time & $\begin{array}{l}\mathbf{E} \\
\mathbf{T}\end{array}$ \\
\hline \multirow{8}{*}{ Existential } & \multirow{2}{*}{ Death } & 1. Her husband's illness and death & 5 & \multirow{2}{*}{$\begin{array}{l}\text { E-2 } \\
\text { T-6 }\end{array}$} \\
\hline & & 2. Illness and death of her siblings & 1 & \\
\hline & \multirow{3}{*}{ Illness } & 1. Her stay in the nursing home & 1 & \multirow{3}{*}{$\begin{array}{l}\text { E-3 } \\
\text { T-4 }\end{array}$} \\
\hline & & 2. Illness - acute arthritis & 1 & \\
\hline & & 3. Stroke and its consequences & 2 & \\
\hline & \multirow{2}{*}{$\begin{array}{l}\text { Unfavourable living } \\
\text { conditions }\end{array}$} & 1. Experience of war and occupation & 11 & \multirow{2}{*}{$\begin{array}{c}\text { E-2 } \\
T-26\end{array}$} \\
\hline & & 2. Life in the nursing home & 15 & \\
\hline & $\begin{array}{l}\text { Favourable living } \\
\text { conditions }\end{array}$ & 1. Childhood spent in her family home & 5 & $\begin{array}{l}\text { E-1 } \\
\text { T-5 }\end{array}$ \\
\hline \multirow{6}{*}{ Social } & \multirow{3}{*}{ Relations with family } & 1. Childhood spent in her family home & 5 & \multirow{3}{*}{$\begin{array}{l}\text { E-3 } \\
\text { T-7 }\end{array}$} \\
\hline & & 2. Caring for the sick brother & 1 & \\
\hline & & 3. Death and illness of her siblings & 1 & \\
\hline & \multirow{3}{*}{$\begin{array}{l}\text { Meeting new people/ } \\
\text { Work with people }\end{array}$} & 1. Work at FSO company & 5 & \multirow{3}{*}{$\begin{array}{l}\text { E-3 } \\
\text { T-12 }\end{array}$} \\
\hline & & $\begin{array}{l}\text { 2. Work as a social worker in SGPiS } \\
\text { (Main School of Planning and Statistics) }\end{array}$ & 2 & \\
\hline & & 3. Work as the head of professor's club & 5 & \\
\hline \multirow{7}{*}{ Emotional } & \multirow{4}{*}{ Love } & 1. Childhood spent in her family home & 5 & \multirow{4}{*}{$\begin{array}{c}\text { E-4 } \\
\text { T-12 }\end{array}$} \\
\hline & & 2. Meeting her future husband & 1 & \\
\hline & & 3. Husband's support and advice regarding the studies & 1 & \\
\hline & & 4. Husband's illness and death & 5 & \\
\hline & Friendship & 1. Friends' help after her husband's death & 1 & $\begin{array}{l}\text { E-1 } \\
\text { T-1 }\end{array}$ \\
\hline & \multirow{2}{*}{$\begin{array}{l}\text { Feelings unrelated to } \\
\text { people }\end{array}$} & 1. Love of nature & 2 & \multirow{2}{*}{$\begin{array}{l}\text { E-2 } \\
\text { T-4 }\end{array}$} \\
\hline & & 2. Caring for her white cat & 2 & \\
\hline \multirow{4}{*}{$\begin{array}{l}\text { Connected with } \\
\text { knowledge } \\
\text { acquisition }\end{array}$} & \multirow{4}{*}{ School/ university } & 1. Asking questions to parents & 3 & \multirow{4}{*}{$\begin{array}{c}\text { E-4 } \\
\text { T-13 }\end{array}$} \\
\hline & & 2. Education during the war & 2 & \\
\hline & & 3. Education in the secondary and technical schools & 6 & \\
\hline & & 4. Social rehabilitation studies & 2 & \\
\hline \multirow{7}{*}{$\begin{array}{l}\text { Connected with } \\
\text { activity }\end{array}$} & \multirow{5}{*}{ Career } & 1. Work at ZUS (Social Insurance Institution) & 1 & \multirow{5}{*}{$\begin{array}{c}\text { E-5 } \\
\mathrm{T}-14\end{array}$} \\
\hline & & 2. Work at FSO company & 5 & \\
\hline & & $\begin{array}{l}\text { 3. Work as a social worker in SGPiS } \\
\text { (Main School of Planning and Statistics) }\end{array}$ & 2 & \\
\hline & & 4. Work as the head of professor's club & 5 & \\
\hline & & 5. Work in an estate council & 1 & \\
\hline & \multirow{2}{*}{ Interests/Passions } & 1. Education at secondary technical school of fine arts & 2 & \multirow{2}{*}{$\begin{array}{l}\text { E-2 } \\
\text { T-3 }\end{array}$} \\
\hline & & 2. Sewing clothes & 1 & \\
\hline
\end{tabular}

E - a total number of experiences relating to a given topic

$\mathrm{T}-\mathrm{a}$ total amount of time devoted to a given topic in the story 
B) Formal analysis

In table 1 experiences mentioned in Mrs I.'s story together with the time devoted to them have been assigned to particular topics. The summary of the number of experiences listed under each topic and the total time dedicated to it has been made.

In tables 2 and 3 the longest and most frequently discussed topics by Mrs I. have been presented.

Table 2. The longest discussed topics by Mrs I.

\begin{tabular}{lc}
\hline \multicolumn{1}{c}{ Topic } & Time (min.) \\
\hline Experience of injustice/dishonesty & 28 \\
\hline Unfavourable living conditions & 26 \\
\hline
\end{tabular}

Career

Fight for herself and her own

convictions

\begin{tabular}{lc}
\hline School/ university & 13 \\
\hline Love & 12 \\
\cline { 1 - 1 } Meeting new people/ Work with people & \\
\hline Failure & 11 \\
\hline
\end{tabular}

Table 3. The most frequently discussed topics by Mrs I.

\begin{tabular}{cc}
\hline Topic & $\begin{array}{c}\text { No. of } \\
\text { experiences }\end{array}$ \\
\hline
\end{tabular}

Fight for herself and her own

convictions

6

Experience of injustice/dishonesty

\begin{tabular}{ll}
\hline Success & 5 \\
\hline Failure & \\
\hline Personal development & 4 \\
\hline Love & \\
\hline Career & \\
\hline
\end{tabular}

The summary of formal analysis results (Mrs I.)

The experience of injustice and dishonesty as well as unfavourable living conditions were the topics to which Mrs I. devoted the greatest amount of time in her story. This may result from the fact that these meanings are the most present in her current life. The number of experiences relating to the 'experience of injustice' indicates that Mrs I. is particularly sensitive to this aspect of her experience. The results of formal analysis demonstrate that she puts a lot of attention to the topics such as career, defence of herself and her convictions, meeting new people and working with them. Mrs I. manifests an active attitude towards the world. There are successes and failures in her experiences, therefore she finds some sense in both dark as well as bright sides of the world. Love of relatives is also essential for her.

C) Analysis of connections between experiences and feelings as well as reflections of an individual

In table 4 Mrs I.'s most essential utterances relating to particular experiences have been presented.

In table 5 conclusions regarding the feelings and meanings connected with particular experiences have been made on the basis of Mrs I.'s utterances (see table 4).

\section{D) Synthesis of C and B stages}

Thanks to stage $\mathrm{C}$ it has been observed that respondent's childhood was very important for her, because it provided her with the feeling of happiness and faith in values. In stage B the analysis has revealed that Mrs I. pays great attention to the experience of injustice and dishonesty. The results of stage $\mathrm{C}$ have demonstrated that the sensitivity to such type of situations is connected with the values which she acquired in her childhood and which she tries to implement in her life. It has also been noticed that activeness and active opposition to injustice are essential for Mrs I. in such situations.

On the basis of formal analysis it has been discovered that the situations in which Mrs I. had to fight for herself and for her own convictions were very important in her life. Stage $\mathrm{C}$ has shown that the fight for herself is an essential element of her active attitude towards the world and a form to maintain her identity in difficult situations. Both stages of the analysis have indicated to the role which Mrs I.'s career and education played in her life. Contact with other people, which - despite difficulties - enabled her to live in accordance with her own convictions as well as provided her with a sense of competence and inner strength, was of vital importance in her work. Mrs I. was curious about the world, therefore education and learning new things was important to her in itself. Stage B has revealed that love for relatives was crucial for her, while thanks to stage $\mathrm{C}$ it has been observed that love was important to her because of the mutual support and understanding.

At the stage of formal analysis it has become very apparent that Mrs I. pays great attention to unfavourable living conditions, which connects with the experience of rebellion and helplessness towards the activities of the nursing home, as observed in stage $\mathrm{C}$. This stage has shown that despite bad living conditions the respondent accepts her reality and still pays great attention to independence and contact with people.

There are no apparent logical inconsistencies between stages $\mathrm{B}$ and $\mathrm{C}$.

\section{E) Synthesis of stages D and A}

Described in the pre-comprehension attitude of the narrator, who to a small degree refers to feelings, agrees with the proactive attitude of Mrs I., who pays fairly much attention to activeness. The emphasis which appears when Mrs I. speaks about events that are unjust in her opinion confirms that this is a topic of great importance for her. 
Table 4. Mrs I.'s utterances important in the context of particular experiences

\section{Experience}

Career, work with people

Relations with

her husband

\section{Utterances}

'In that period the joy of life was very important to me'. 'I didn't think about what was the worst in life, but about what is important in life'. 'I was told that family which sticks together is the life of a human, that parents' task is to bring up healthy, positive and affectionate children', 'Living in that environment, I had an opportunity to observe life. There was no brutality in that life of mine.'

'Experiences which contributed to my life failure, some kind of a total change'. 'I experienced various very unpleasant and frightening moments'. 'Both adults and children were engaged in brutal works. Their needs were not recognised'. 'Watching one German beating my father, I grabbed a stone and hit him'. 'I was able to acquire some sort of cleverness'. 'I was able to convince them about the fact that they - as Germans - stole from that German, so that we could heat our apartment'.

Education $\quad$ 'I fell in love with the German language and I wanted to know more...' 'I learnt how to write and I soaked it up with great enthusiasm'. 'This required concentration and abilities, but I managed'.

'I have always taken life seriously.' 'I told the manager that this was my whole evident truth.' 'So, this wasn't easy for me, because work with people is always troublesome as we are so different'. 'People wrote letters and complained (...), all this cumulated in me, all the time'. 'But I survived it all and I regret nothing, because I pay attention to current affairs in life, to communication with people, to helping them; I was brought up that way'. 'Such reflection struck me that for my whole life I worked for people and people who worked for others worked for themselves.'

'Appreciating me, because I always valued his abilities and skills, (...) my husband talked me into starting studying'. 'I suffered some sort of a family defeat, because my husband had successive heart attacks.'

'What is a bitter experience of my life is the fact that I have to stay in the so-called nursing home, but I don't intend to lament about it, because I am aware of life and the truth is that 'whoever was born must die', and as I was born in the 30's, then this is already quite a long time'. 'Having

Illness and stay comparison, I know for a fact that a social worker should care for sick people'. 'All the time I was in the nursing so independent and I didn't want any pity and when this stroke affected me - I also coped with it'. home 'You don't always find the joy of life here (...); nevertheless, I try to shape this independence in myself'. 'It's difficult to get used to this huddle (...); you need to have your own invention as long as possible'. 'There is a lot of red tape here'. 'Everything seems so appalling'. 'It horrifies me but I can't put the cart before the horse'.

Table 5. Feelings and meanings connected with Mrs I.'s experiences

\begin{tabular}{ll}
\hline \multicolumn{1}{c}{ Experience } & \multicolumn{1}{c}{ Feelings and meanings } \\
\hline & $\begin{array}{l}\text { Feelings: acceptance, exploration of the world and her own capabilities, safety, joy, sense of life, } \\
\text { attachment, trust. }\end{array}$ \\
\cline { 2 - 3 } Childhood & $\begin{array}{l}\text { Meanings: The experience of childhood exerted its influence on Mrs I.'s personal, emotional and } \\
\text { existential context. This experience is vital to her because of the joy which it gave her and because } \\
\text { of the values which she learnt in that period such as: the value of family and love of nature. }\end{array}$ \\
\hline & $\begin{array}{l}\text { Feelings: confusion, vulnerability, imposition, limitation, but also independence and inner strength. } \\
\text { Period of war }\end{array}$ \\
$\begin{array}{l}\text { Meanings: The experience of war also had an impact on the respondent's personal, emotional and } \\
\text { existential as well as moral context. The meaning of this experience is such that, despite difficult } \\
\text { and horrific living conditions, it did not have a destructive effect on the respondent's psyche; } \\
\text { on the contrary, it pushed her to find inner strength and courage. Rebellion against evil and } \\
\text { injustice may be another meaning. }\end{array}$
\end{tabular}


Experience

Feelings and meanings

Feelings: self-confidence, belief in her own competences, activity, enthusiasm.

Education

Meanings: The experience of education is included in the personal sphere as well as associated with the acquisition of knowledge and with activity. For the respondent education is crucial, because it boosts self-confidence, generates satisfaction and a feeling of better understanding of the world.

Feelings: self-confidence, courage, belief in her own competences, being herself, inner strength, but also the sense of lack of understanding and experience of difficulty.

Career, work with Meanings: The experience of her career had an influence on the social and existential spheres as people well as spheres connected with activity and morality in the respondent's life. It can be observed that this is a particularly important experience for the formation of her identity. As she indicates, it is rooted in the values learnt in childhood and despite difficulties it provides meaning to her life. Rebellion against other people's immoral behaviour is also connected with this experience.

\begin{tabular}{ll} 
Relations with $\begin{array}{l}\text { Feelings: acceptance, understanding. } \\
\text { her husband }\end{array}$ & $\begin{array}{l}\text { Meanings: The relation with her husband was very important to the respondent, because it provided } \\
\text { her with a feeling of mutual acceptance, support and respect. }\end{array}$ \\
\cline { 2 - 3 } & $\begin{array}{l}\text { Feelings: limitation, lack of understanding, sensitivity, helplessness, confusion as well as } \\
\text { acceptance, independence, courage, activeness, sense of life. }\end{array}$ \\
\cline { 2 - 2 } $\begin{array}{l}\text { Her stay in the } \\
\text { nursing home }\end{array}$ & $\begin{array}{l}\text { Meanings: The stay in the nursing home is difficult for Mrs I., because it arouses rebellion in her } \\
\text { against the experienced injustice and activities inconsistent with her values. Nevertheless, she } \\
\text { remains faithful to them and takes action to remain herself. Despite the experienced difficulties, } \\
\text { she accepts her situation. The fight for independence is particularly important for her in this period. }\end{array}$
\end{tabular}

It has already been noticed in pre-comprehension that the story protagonist is very independent. Stage D has indicated that Mrs I. draws great attention to relations with people, but there are few descriptions of the protagonist's relations with other characters of the story in the pre-comprehension. This may indicate that these relations are important for her more at the level of action rather than feelings.

\subsection{Interpretation of Mrs J.'s story}

\section{A) Pre-comprehension}

The narrator and the story protagonist seem to intertwine, because Mrs J. often speaks about her feelings and she also seems to re-live these experiences in the course of the story telling. Only in the last fragment of the story does the protagonist seem to vanish and the narrator's attention is entirely focused on the sick husband.

The story is dominated by feelings. It appears that they bind the whole of her story and by their presence the past intertwines with the present. The story structure is not determined by chronology. Mrs J.'s narration seems to be the essence of what is important in her life. In the story good and joyful things mingle with those that are difficult and painful.

\section{B) Formal analysis}

Experiences mentioned in Mrs J.'s story together with the time devoted to them have been assigned to particular topics. The summary of the number of experiences listed under each topic and the total time dedicated to it has been prepared (table 6).

In tables 7 and 8 the longest and most frequently discussed topics by Mrs J. have been presented.

\section{The summary of formal analysis results (Mrs J.)}

Love and friendship are the topics which were discussed the longest in the story and to which the biggest number of experiences refers. Therefore, it is clear that Mrs J. pays great attention to closeness with other people, both belonging to her family and those accidentally encountered in her life. Experiences connected with her husband's illness and death occupy an important place in her life story, which is considerably connected, in her case, with the meaning attached to love. Career and the experience of success stemming from it are another topic crucial to Mrs J.

C) Analysis of connections between experiences and feelings as well as reflections of an individual

In table 9 Mrs J.'s most essential utterances relating to particular experiences have been presented.

In table 10 conclusions regarding the feelings and meanings connected with particular experiences have been made on the basis of Mrs J.'s utterances included in table 9. 
Table 6. Frequency of topics in Mrs J.'s story and the time devoted to them

\begin{tabular}{|c|c|c|c|c|}
\hline Experience context & Topic of experience & Events & Time & $\begin{array}{l}\mathbf{E} \\
\mathbf{T}\end{array}$ \\
\hline \multirow{3}{*}{ Personal } & Loss & Her husband's illness and death & $\mathrm{T}-8$ & $\begin{array}{l}\text { E-1 } \\
\text { T-8 }\end{array}$ \\
\hline & Success & Work as an accountant & $\mathrm{T}-5$ & $\begin{array}{l}\text { E-1 } \\
\text { T-5 }\end{array}$ \\
\hline & Fight for relatives & Care for her husband and son & $\mathrm{T}-2$ & $\begin{array}{c}\text { E-1 } \\
\mathrm{t}-2\end{array}$ \\
\hline \multirow{4}{*}{ Existential } & Death & Her husband's illness and death & $\mathrm{T}-8$ & $\begin{array}{l}\text { E-1 } \\
\text { T-8 }\end{array}$ \\
\hline & Illness & Her husband's illness and death & $\mathrm{T}-8$ & $\begin{array}{l}\text { E-1 } \\
\text { T-8 }\end{array}$ \\
\hline & Favourable living conditions & Work as an accountant & $\mathrm{T}-5$ & $\begin{array}{l}\text { E-1 } \\
\text { T-5 }\end{array}$ \\
\hline & Loneliness & Experience of old age and loneliness & $\mathrm{T}-2$ & $\begin{array}{l}\text { E-1 } \\
\text { T-2 }\end{array}$ \\
\hline \multirow{4}{*}{ Social } & \multirow{2}{*}{ Relations with family } & Relation with her son & $\mathrm{T}-2$ & \multirow{2}{*}{$\begin{array}{l}\text { E-2 } \\
\text { T-5 }\end{array}$} \\
\hline & & Current relations with family & $\mathrm{T}-3$ & \\
\hline & Work with people & Work as an accountant & $\mathrm{T}-5$ & $\begin{array}{l}\text { E-1 } \\
\text { T-5 }\end{array}$ \\
\hline & Social relations & Relation with friends & $\mathrm{T}-1$ & $\begin{array}{l}\text { E-1 } \\
\text { T-1 }\end{array}$ \\
\hline \multirow{6}{*}{ Emotional } & \multirow{3}{*}{ Love } & Her husband's illness & $\mathrm{T}-8$ & \multirow{3}{*}{$\begin{array}{c}\text { E-3 } \\
\text { T-13 }\end{array}$} \\
\hline & & Relation with her son & $\mathrm{T}-2$ & \\
\hline & & Current relations with family & $\mathrm{T}-3$ & \\
\hline & \multirow{3}{*}{ Friendship } & Career & $\mathrm{T}-5$ & \multirow{3}{*}{$\begin{array}{l}\text { E-3 } \\
\text { T-8 }\end{array}$} \\
\hline & & Departure from work & $\mathrm{T}-2$ & \\
\hline & & Relation with friends & $\mathrm{T}-1$ & \\
\hline Connected with activity & Career & Work as an accountant & $\mathrm{T}-5$ & $\begin{array}{l}\text { E-1 } \\
\text { T-5 }\end{array}$ \\
\hline
\end{tabular}

$\mathrm{T}-\mathrm{a}$ total amount of time devoted to a given topic in the story

$\mathrm{E}-\mathrm{a}$ total number of experiences relating to a given topic

Table 7. The longest discussed topics

\begin{tabular}{lc}
\hline \multicolumn{1}{c}{ Topic } & Time (min) \\
\hline Love & 13 \\
\hline Loss, death, illness & 8 \\
\hline Friendship & 8 \\
\hline Career & 5 \\
\hline Relations with family & 5 \\
\hline Success & 5 \\
\hline
\end{tabular}

Table 8. The most frequently discussed topics

\begin{tabular}{lcc}
\hline & Topic & No. of experiences \\
\hline Love & 3 \\
\hline Friendship & 3 \\
\hline
\end{tabular}


Table 9. Mrs J.'s utterances important in the context of particular experiences

\section{Experience}

Career

'This lies in my nature that when I do something, I do it well'. 'I worked at different positions with great responsibility'. 'I was always liked'. 'These were pleasant, nice relations'. 'And I say to them: «You are like my children»'. 'I always liked my work and I didn't see myself anywhere else'.

\begin{tabular}{ll}
\hline $\begin{array}{l}\text { Her husband's } \\
\text { and son's } \\
\text { illnesses }\end{array}$ & $\begin{array}{l}\text { 'This was such a hard period, because he was ill for long'. 'The doctor's judgement that we heard } \\
\text { was horrific for us'. 'But then, I visited both of them smiling and contented'. 'I couldn't show him, } \\
\text { that sick young man, that I am so emotional about it, that I am so miserable...' }\end{array}$ \\
$\begin{array}{ll}\text { Current relations } \\
\text { with family }\end{array}$ & $\begin{array}{l}\text { 'I enjoy these grandchildren of mine'. 'And this is currently my greatest value'. 'Children that } \\
\text { love and are loved, a truly successful family'. 'I have a wonderful family. Well, now it is probably } \\
\text { the most important thing after all'. }\end{array}$ \\
$\begin{array}{l}\text { Loneliness } \\
\text { at an old age }\end{array}$ & $\begin{array}{l}\text { 'But despite everything, I am a little bit lonely, though'. 'Somehow I miss my other half, because } \\
\text { should live together till the end, because at an old age everyday closeness is needed'. }\end{array}$ \\
\hline
\end{tabular}

Table 10. Feelings and meanings connected with Mrs J.'s experiences

\begin{tabular}{|c|c|}
\hline Experience & Feelings and meanings \\
\hline \multirow[b]{2}{*}{ Career } & $\begin{array}{l}\text { Feelings: acceptance, independence, self-confidence, responsibility, belief in her own competences, } \\
\text { liberty, safety. }\end{array}$ \\
\hline & $\begin{array}{l}\text { Meanings: Work has a great value for the personal and emotional context of Mrs J.'s life. It provided } \\
\text { her with the sense of competence and personal fulfilment as well as with closeness, safety and } \\
\text { friendship. For Mrs J. work is essential, because she gained independence thanks to it. The fact that } \\
\text { she managed in life by herself makes her proud and satisfied. }\end{array}$ \\
\hline \multirow[b]{2}{*}{$\begin{array}{l}\text { Her husband's } \\
\text { and son's } \\
\text { illnesses }\end{array}$} & Feelings: responsibility, sensitivity, helplessness, suffering, inner strength \\
\hline & $\begin{array}{l}\text { Meanings: This experience exerted a great influence on Mrs J.'s personal, emotional and existential } \\
\text { dimension of life. It was an extremely difficult and painful event, which she had to encounter } \\
\text { with inner strength and responsibility for her relatives. Considering her husband's death, } \\
\text { the presence of her son, who filled the void after his father, was of great importance to her. }\end{array}$ \\
\hline \multirow[b]{2}{*}{$\begin{array}{l}\text { Current relations } \\
\text { with family }\end{array}$} & Feelings: acceptance, attachment, joy, sense of life \\
\hline & $\begin{array}{l}\text { Meanings: Family occupies an important place in Mrs J.'s life both in emotional and existential } \\
\text { aspects. It makes her feel loved and provides her with a lot of joy. Thanks to family, she achieved } \\
\text { success in life, which rewarded her suffering. }\end{array}$ \\
\hline \multirow{2}{*}{$\begin{array}{l}\text { Loneliness } \\
\text { at an old age }\end{array}$} & Feelings: sorrow, longing, sense of lack \\
\hline & $\begin{array}{l}\text { Meanings: Despite the presence of her loving family and numerous social relations, Mrs J. suffers } \\
\text { from the lack of a loved person such as her husband. }\end{array}$ \\
\hline
\end{tabular}

D) Synthesis of stages B and C

On the basis of stage $B$ it has been observed that relations with close people, her career as well as her husband's illness are of great importance to Mrs J. Thanks to stage $\mathrm{C}$ it has been noticed that love and family relations provide Mrs J. with joy and they are also important for her in the existential dimension, ensuring a sense of purpose and compensating for all the suffering that happened to her in life. Mrs J.'s husband's illness was important for her not only because of her love for him, but also because it required inner strength that she had to find in herself in order to be able to support him. In her career, Mrs J. paid much attention to the sense of competence and success as well as to friendly relations and atmosphere.

\section{E) Synthesis of stages D and A}

Already in pre-comprehension it has been observed that feelings are important for Mrs J. The remaining stages of interpretation have confirmed this observation. 


\subsection{Verification of interpretation correctness}

The correctness of interpretation has been verified on the basis of a survey designed for that purpose (for a sample survey - see Annex 1). The degree of consistency between Mrs I.'s opinion and the researcher's interpretation amounted to $\mathrm{DC}=94.5 \%$. In the case of eight statements, Mrs I. ticked ' 5 ' on the scale, i.e. 'totally agree', and only with three statements she chose rating '4', i.e. 'agree'. After completing the survey, she was very pleased. She said that she had the feeling that far-reaching conclusions had been drawn on the basis of her story and expressed joy at the fact that she could familiarise herself with them.

The degree of consistency between Mrs J.'s opinion and the researcher's interpretation amounted to $\mathrm{DC}=94.4 \%$. In the case of four statements Mrs J. ticked rating ' 5 ' and with two others - ' 4 '. Commenting on the survey, she expressed the opinion that the person conducting the research had understood her very well and stressed how important family was in her opinion.

\section{Discussion and conclusions}

Each of the respondents is perceived through her narration as a unique person whose system of meanings cannot be examined limiting only to quantitative data. Differences between them manifest themselves even at the level of narration structure. Mrs I. tells her story in a chronological order while Mrs J. mentions only the most important events of her life. Both women regard relations with others as important, but each of them defines these relations in a different way: Mrs J. perceives them mainly at the level of feelings while for Mrs I. the context of activity is important in them.

Qualitative methods are necessary to fully reflect the subjective nature of human life. According to the assumptions of philosophical anthropology humans search for some sense in the events that they encounter. At the beginning of Mrs I.'s story, she mentioned about her bitter experience: her stay in the nursing home. At the same time, however, she added, referring to the saying 'Whoever is born must die', that in some way she accepted this experience, appreciating that she had been given so many years of life. Similarly, talking about her husband's illness and death, Mrs J. stated that her son and wonderful family were a reward for the suffering that had happened to her. In the stories of both women one may also observe the manner in which they implemented their existential freedom in life. Satisfying the need to acquire knowledge, Mrs I. enrolled on new fields of study, abandoning those that failed to satisfy her. On the other hand, Mrs J. stated that despite the fact that many people did not appreciate the job that she had done, she was very happy with this choice.

The distinction between the activity of 'the objective self' and 'the subjective self' is clearly visible in the lives of the respondents. In the situation of Mrs J.'s husband's and son's illness, despite the suffering, she managed to direct herself to provide support and comfort to her beloved ones. In the situation of her husband's death, also Mrs I. refused a sedative injection in the name of the professed principle that one should have a clear-headed approach to life. On the basis of these stories, it can be observed that 'subjective Self' has the power of control over the psychological processes taking place in it, even in the most difficult moments of life.

The interpretation of both narratives has documented that, in accordance with Landgrebe's theory (1968), meanings communicated by an individual relate to the attempt to understand his/her own position designated by events of the surrounding world and by his/her own free choices and decisions. Mrs I. devoted a lot of time to the description of her situation during the war as well as to the living conditions in the nursing home. Therefore, it may be observed that in such moments external circumstances independent of her had an influence on her situation. At the same time, however, referring to both of these situations, Mrs I. mentioned her attempts to counter the hostile living conditions. During the war, it was very important for her to acquire cleverness, which enabled her to obtain coal from Germans for her family, while in the nursing home the struggle to maintain independence as well as informing the municipality authorities about the director's unfairness were her forms of opposition. These actions were an expression of her free will and subjectivity to the conditions on which she had no influence. Also in Mrs J.'s story one can observe the attempt to understand her changing position. Speaking about her husband's and son's illnesses, which were completely beyond her control, Mrs J. talks about her effort to preserve external buoyancy, thanks to which she could support her loved ones.

The presented research also seems to confirm Ricoeur's theory (1989) that the formulation and communication of meanings occur through dialogue with other people. During their stories both ladies repeatedly referred to the researcher, to whom they explained various matters, used such phrases as 'do you understand?', 'you know', 'you see' or even asked short questions. While talking, they also exhibited strong emotions. Therefore, the presence of the self-narrative listener seems to constitute a very important factor motivating the respondents to disclose personal meanings.

Leaving the time for the respondents to rethink their stories also had a positive effect. Both ladies prepared themselves to the second meeting with the researcher by making brief notes. Therefore, it is evident that they needed this time in order to be able to reflect on their own lives. Because they touched topics important to them and communicated crucial meanings in their stories, it may be concluded that the content of the prepared narrative stimulus as well as the manner in which the interview had been conducted were correct and encouraged the disclosure of subjective meanings. It is not known, however, whether another type of method would not lead the respondents to reveal a bigger number of meanings or meanings with more in-depth content.

The posed hypothesis concerning the correctness of the applied method of interpretation has been confirmed, as the degree of consistency between the interpretation of respondent's opinion significantly exceeded $70 \%$ in 
both cases. A positive response of both women to the presented survey has also been a significant indicator for the correctness of this method. Therefore, the method of interpretation developed according to the assumptions of hermeneutic psychology has enabled the identification of parts of meanings communicated by the subject. It is not known, however, how many meanings included in the stories have not been recognised. Verification of various methods of interpretation taking into account a larger sample of respondents is necessary in order to determine their effectiveness in coming close to subjective meanings contained in stories.

The manner of the verification of results applied in the research was accepted and appreciated by the respondents. Feedback included in the survey could be some sort of a reward for them for the participation in the research. Including such type of methods into the procedure of qualitative research is therefore beneficial.

\section{References}

Bartosz, B. (2004). Ludzie chcą opowiedzieć swoją historię. Konstruowanie rzeczywistości $\mathrm{w}$ narracji [People want to tell their story. Constructing reality in a narrative]. In E. Dryll, \& A. Cierpka (eds.), Narracja. Koncepcje i badania psychologiczne [Narration. Concepts and psychological studies] (pp. 229-240). Warsaw: Wydawnictwo Instytutu Psychologii PAN.

Bobryk, J. (1981). Spoleczne podstawy Ja podmiotowego [Social basis of subjective Self]. Warsaw: Wydawnictwa Uniwersytetu Warszwskiego.

Denzin, N.K., Lincoln, Y.S. (eds.) (2005). The Sage handbook of qualitative research, $3^{\text {rd }}$ edition. London-Thousand Oaks-New Delhi: SAGE.

Dilthey, J. (1982). Pisma estetyczne [Aesthetic writigs]. Warsaw: Państwowe Wydawnictwo Naukowe.

Dilthey, J. (1993). Rozumienie i życie [Understanding and life]. In G. Sowiński (ed.), Wokól rozumienia. Studia i szkice z hermeneutyki [Around understanding. Studies and sketches on hermeneutics]. Krakow: Papieska Akademia Teologiczna.

Elsbree, L. (1982). The rituals of life: Pattern in narratives. Washington: Kennikat Press.

Frye, N. (1963). Fables of identity. Studies in Poetic Mythology. New York: Harcourt Brace.

Gadacz, T. (1997). Poznawać, czy rozumieć? Hermeneutyczne podstawy filozofii człowieka [Cognise or understand? Hermeneutic basics of human philosophy]. In A. Gałdowa (ed.), Hermeneutyka a psychologia [Hermeneutics vs psychology] (pp. 10-17). Krakow: Wydawnictwo Uniwersytetu Jagiellońskiego.
Gergen, K., \& Gergen, M. (2011). Narrative tensions: Perilous and productive. Narrative Inquiry, 20(2), 374-381. doi: 10.1075/ni.21.2.17ger Helling, I.K. (1990). Metoda badań biograficznych [The method of biographical research]. In J. Włodarek, \& M. Ziółkowski (eds.), Metoda biograficzna $w$ socjologii [The biographical method in sociology] (pp. 20-34). Warsaw-Poznan: PWN.

Hermans, H.J.M., \& Hermans-Jansen, E. (1995). Self-narratives. The construction of meaning in Psychotherapy. New York-London: The Gulford Press, Inc.

Landgrebe, L. (1968). Phänomenologie und Geschichte. Gütersloh: Gütersloher Verlagshaus G. Mohn.

Maruszewski, T. (2011). Psychologia poznania. Umyst i świat [Psychology of cognition. Mind and world]. Sopot: Gdańskie Wydawnictwo Psychologiczne.

McAdams, D.P. (1993). Stories we live by: Personal myths and the making of the self: New York, NY: William Morrow and Company, Inc.

Pervin, L.A., \& John, O.P. (1997). Personality: Theory and research ( $7^{\text {th }}$ ed.). New York: Wiley.

Radnitzky, G. (1970). Contemporary schools of metascience. Gothenburg Akademiforlaget.

Ricoeur, P. (1989). Jezyk, tekst, interpretacja [Language, text, interpretation]. Warsaw: Państwowy Instytut Wydawniczy.

Ricoeur, P. (1992). Filozofia osoby [Philosophy of a person]. Krakow: Papieska Akademia Teologiczna.

Ricoeur, P., \& Thompson, J.B. (1981). Hermeneutics and the human science: Essays on language action and interpretation. Cambridge: Cambridge University Press.

Riessman, C.K. (2008). Narrative methods for the human sciences. London: Sage Publications.

Sarbin, T.R. (1986) (red.). Narrative psychology. The storied nature of human conduct. New York: Praeger.

Straś-Romanowska, M. (2000). O metodzie jakościowej w kontekście rozważań nad tożsamością psychologii [On the qualitative method in the context of reflection on the identity of psychology]. In M. Straś-Romanowska (ed.), Metody jakościowe $w$ psychologii wspótczesnej [Qualitative methods in modern psychology] (pp. 15-30). Wroclaw: Wydawnictwo Uniwersytetu Wrocławskiego.

Straś-Romanowska, M. (2004). Podmiotowość człowieka w badaniach narracyjnych [Human subjectivity in narrative research]. In E. Dryll, \& A. Cierpka (eds.), Narracja. Koncepcje i badania psychologiczne [Narration. Concepts and psychological studies] (pp. 23-36). Warsaw: Wydawnictwo Instytutu Psychologii PAN.

Uchnast, Z. (1983). Humanistyczna orientacja w psychologii osobowości [Humanistic orientation in the personality psychology]. Lublin: Wydawnictwo KUL.

Żurko, M. (2004). Rekonstrukcja poczucia tożsamości na podstawie narracji: Propozycje interpretacji tekstu autobiograficznego [Reconstruction of the sense of identity based on a narrative: Proposals for the interpretation of autobiographical texts]. In E. Dryll, \& A. Cierpka (eds.), Narracja. Koncepcje i badania psychologiczne [Narration. Concepts and psychological studies] (pp. 220-226). Warsaw: Wydawnictwo Instytutu Psychologii PAN. 


\section{ANNEX 1. SURVEY OF INTERPRETATION CORRECTNESS (MRS I.'S STORY)}

On the basis of your story, I have attempted to understand what is important for you in life. Perhaps I have made some mistakes and misunderstood you. I would like to request you to address the results of my work. Because you know best what is important for you, therefore you may regard each of the following sentences incorrect. Your honesty while responding to this survey will enable me to take a critical approach to my work. Please address the following sentences by circling the chosen responses:

1 - strongly disagree

2 - disagree

3 - neither agree nor disagree

4 - agree

5 - strongly agree

1. For me childhood was important because in that period I was happy and experienced parents' love.

$$
1 \ldots . .2 \ldots . .3 \ldots . . . . . .5
$$

2. For me childhood was important because in that period I learnt what was important in life.

$$
1 \ldots . .2 \ldots . .3 \ldots . . . . . .5
$$

3. During the war it was important for me that I could find in myself the strength, courage and cleverness in order to somehow cope with difficult conditions.

$$
1 \ldots . .2 \ldots . .3 \ldots . . . . .5
$$

4. I pay great attention to the situations in which some injustice takes place around me.

$$
1 \ldots . .2 \ldots . . . . . .4 \ldots . .5
$$

5. In life it is important for me to be active, especially in difficult situations for me.

$$
1 \ldots . .2 \ldots . .3 \ldots . .4 \ldots .5
$$

6. Education was important for me, because I was curious about the world and I wished to become acquainted with a lot of new things.

$$
1 \ldots . .2 \ldots . .3 \ldots . . . . . .5
$$

7. My work was important for me, because thanks to it I felt competent and self-confident.

$$
1 \ldots . .2 \ldots . .3 \ldots . .4 \ldots .5
$$

8. Helping people and working with them were difficult for me, but despite that fact I reckon that they gave meaning to my life.

$$
1 \ldots . .2 \ldots . .3 \ldots . .4 \ldots .5
$$

9. In life it was important for me to defend myself and my own convictions.

$$
1 \ldots . .2 \ldots . .3 \ldots . .4 \ldots .5
$$

10. In my marriage mutual support and understanding were important for me.

$$
1 \ldots . .2 \ldots . .3 \ldots . . . . . .5
$$

11. Currently it is important for me to be independent and active with respect to conditions that raise my objection.

$$
1 \ldots . .2 \ldots . .3 \ldots . .4 \ldots .5
$$

